University of Nebraska - Lincoln

DigitalCommons@University of Nebraska - Lincoln

Faculty Papers and Publications in Animal

Science

Animal Science Department

April 2003

\title{
Mapping of porcine ESTs obtained from the anterior pituitary
}

\author{
G. R. Bertani \\ University of Nebraska-Lincoln \\ R. K. Johnson \\ University of Nebraska-Lincoln, rjohnson5@unl.edu
}

A. Robic

Laboratoire de Génétique Cellulaire, INRA, Castanet Tolosan, France

Daniel Pomp

University of Nebraska-Lincoln, dpomp1@unl.edu

Follow this and additional works at: https://digitalcommons.unl.edu/animalscifacpub

Part of the Animal Sciences Commons

Bertani, G. R.; Johnson, R. K.; Robic, A.; and Pomp, Daniel, "Mapping of porcine ESTs obtained from the anterior pituitary" (2003). Faculty Papers and Publications in Animal Science. 73.

https://digitalcommons.unl.edu/animalscifacpub/73

This Article is brought to you for free and open access by the Animal Science Department at DigitalCommons@University of Nebraska - Lincoln. It has been accepted for inclusion in Faculty Papers and Publications in Animal Science by an authorized administrator of DigitalCommons@University of Nebraska - Lincoln. 
Published in Animal Genetics 34:2 (April 2003), pp. 132-134; doi:10.1046/j.1365-2052.2003.00962.x Copyright @ 2003 2003 International Society for Animal Genetics; published by Blackwell Publishing. Used by permission. http://www.blackwell-synergy.com/loi/AGE

Accepted for publication October 17, 2002.

SHORT COMMUNICATION

\title{
Mapping of porcine ESTs obtained from the anterior pituitary
}

\author{
G. R. Bertani ${ }^{1}$, R. K. Johnson ${ }^{1}$, A. Robic ${ }^{2}$, and D. Pomp ${ }^{1,3}$ \\ ${ }^{1}$ Department of Animal Science, University of Nebraska, Lincoln NE, USA. $†$ \\ ${ }^{2}$ Laboratoire de Génétique Cellulaire, INRA, Castanet Tolosan, France \\ ${ }^{3}$ Corresponding author; Email: dpomp@unl.edu
}

\begin{abstract}
We report the physical mapping of porcine expressed sequence tags (ESTs) from anterior pituitary clones isolated by differential display PCR in a study using lines selected for reproduction. These ESTs were mapped using a somatic cell hybrid panel (SCHP) and a radiation hybrid panel (IMpRH) as follows (SCHP position, nearest marker on the RH map): SPARCL1 (8q23-q27, SSP1); ATF4 (5p11-p15, AC02); MEF2C [2(1/2q21)(1/2q22), SW2134]; FTH1 (2p14-p17, SWR783); FRAP1 (6q22-q23, SW1355); PBP (14, SW2508); LOC92004 [13q23-(1/2q41),CP]; and PGRMC1 [Xq22, SW1943]. All RH assignments were at LOD score $>6.0$ except for PGRMC1 at LOD score 5.4. ESTs TCP1 [12p11-(2/3p13)], SF3B1 (15q23-q26) and Clock (8q11-q12) were assigned using only the SCHP. The map position of SPARCL1 coincides with a quantitative trait loci (QTL) for age at puberty found in the University of Nebraska selection lines. Physical mapping of ESTs reported in the present study contributes to characterization of the transcriptome of anterior pituitary of pigs, adds new information to the public database of the porcine genome expression map, and further develops the porcine-human comparative map.
\end{abstract}

Keywords: anterior pituitary, ESTs, mapping, swine.

Genetic maps generated by the use of somatic cell hybrid panels (Yerle et al. 1996) provide information on the physical location of genes and, along with painting studies (Goureau et al. 1996), provide information on synteny conservation across species. Although genetic and physical maps are important for positional cloning and positional candidate gene approaches, they are not comprehensive and significant gaps exist. Higher resolution maps can be obtained by means of radiation hybrid panels (Yerle et al. 1998), and inclusion of temporally and spatially characterized expressed genes onto the radiation hybrid (RH) map help to merge genetic and physiological approaches to gene discovery. The present study reports somatic cell hybrid panel (SCHP) and RH panel mapping of EST markers from clones isolated in an anterior pituitary differential display project (Bertani 2001) designed to identify genes differentially expressed between a line selected for enhanced reproduction and a randomly selected control line (Johnson et al. 1999).

The 11 ESTs described herein represent previously unmapped genes from a total of 168 ESTs that were characterized (excised from gels, purified and sequenced) in the differential display study. Primers for amplifying the
ESTs were designed using Primer3 (Rozen \& Skaletsky 2000). Most of the primers were designed in the 3' UTR. For TCP1 and FTH1, only one primer was designed in the 3' UTR and the Clock and SPARCL1 primers were designed within coding sequence. Primers were then optimized for PCR (Table 1). The SCHP used in this study included 27 hybrids (Yerle et al. 1996). Data were submitted to the somatic cell hybrid panel common database for analysis (http://0-www.toulouse.inra.fr.library.unl.edu/lgc/pig/pcr/pcr. $\underline{\mathrm{htm}})$. Clones of the IMpRH $(n=118$; Yerle et al. 1998) were genotyped for each EST in duplicate. Data were submitted to the IMpRH server (Milan et al. 2000) for analysis against the RH map built by Hawken et al. (1999). Mapping results for SCHP and RH panels are presented in Table 2. Of the mapping assignments for the 11 genes in the present study, all are in agreement with painting studies (Goureau et al. 1996) and confirm previously known pig-human conservation, except for $T C P 1$. In the case of $T C P 1$, results from RH mapping place this gene in the extremity of a linkage group (Hawken et al. 1999) on chromosome 1 with a LOD score of 4.4, or alternatively, linked to $S W 943$ on chromosome 12 with a LOD score of 3.04. While assignment of TCP1 to SSC12 is in agreement 
Table 1 Information on mapped ESTs isolated from pig anterior pituitary and their PCR amplification conditions.

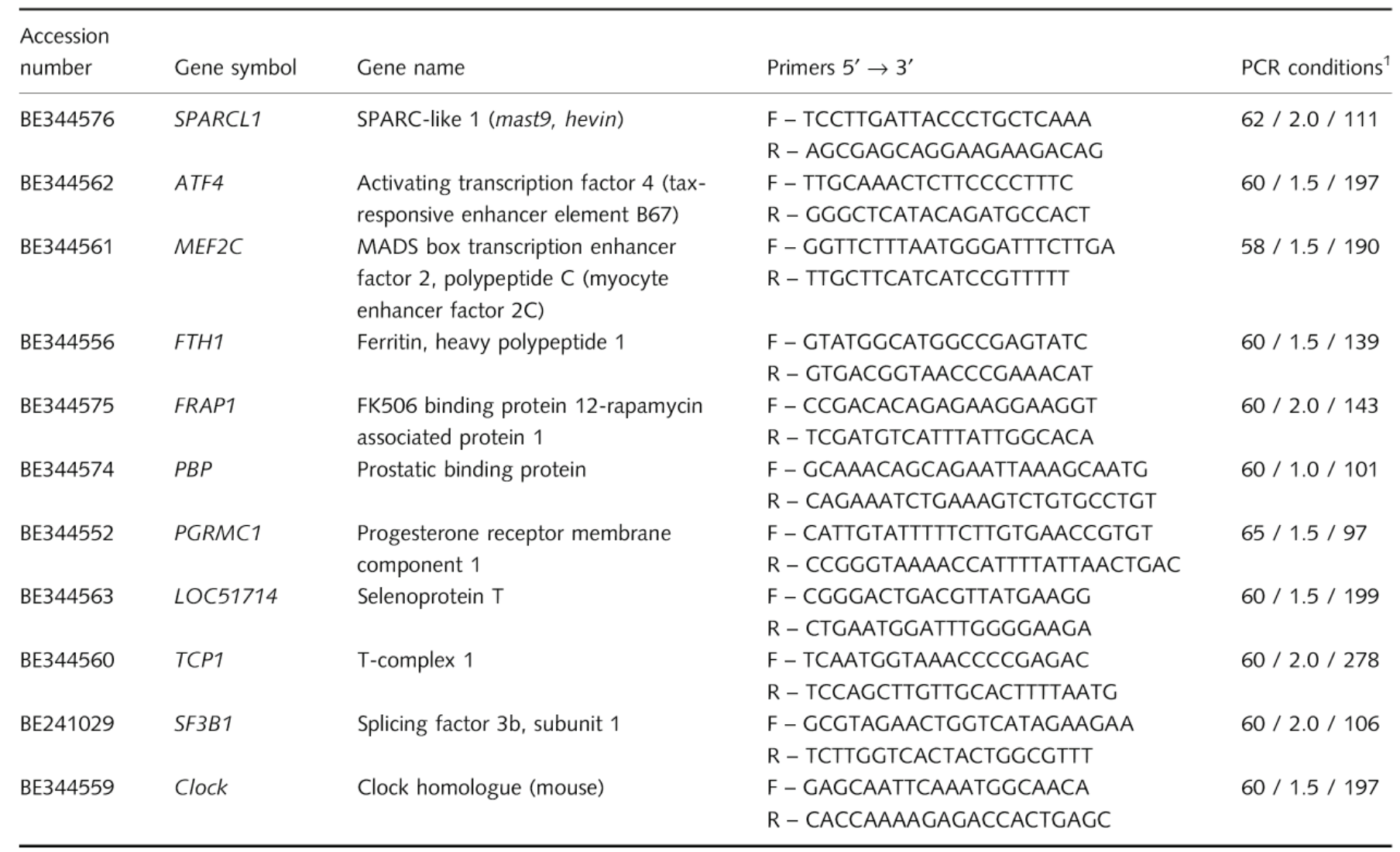

${ }^{1}$ Optimal annealing temperature in ${ }^{\circ} \mathrm{C} / \mathrm{MgCl}_{2}$ concentration in $\mathrm{mm} /$ length of amplified fragment in base pairs.

Table 2 Somatic cell hybrid panel and radiation hybrid panel mapping results, and comparative mapping data, for ESTs isolated from pig anterior pituitary.

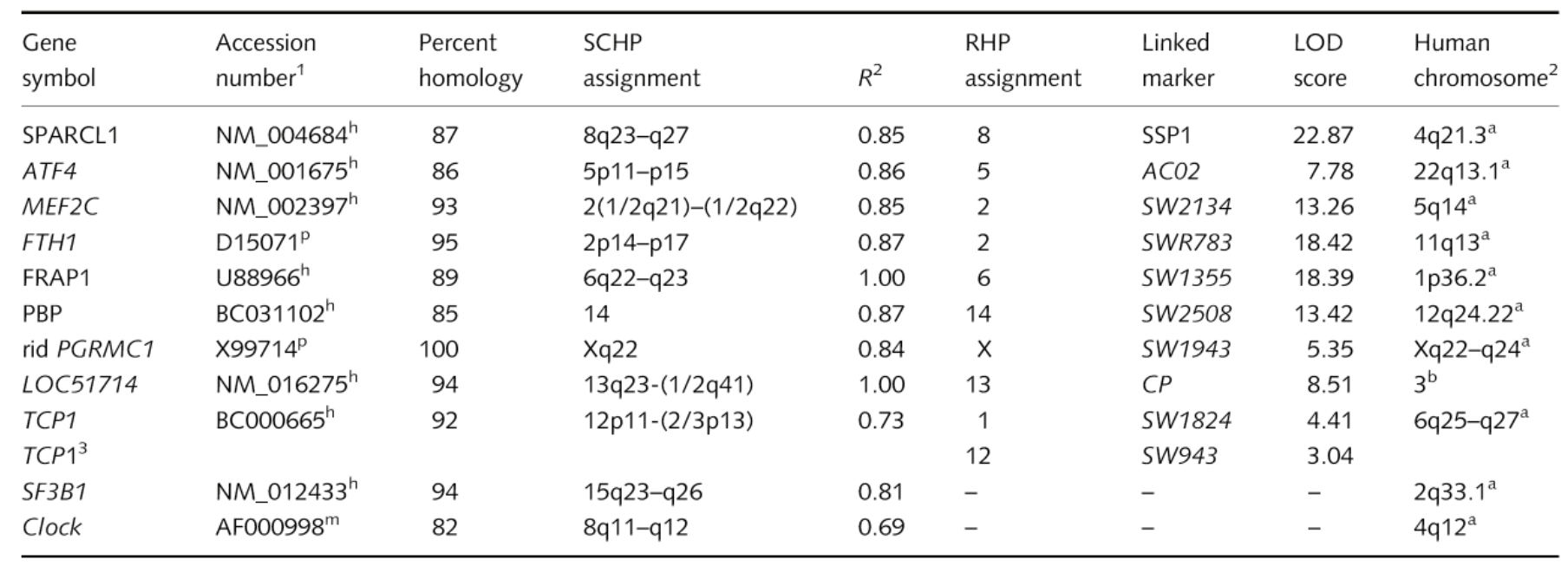

${ }^{1}$ Accession number of DNA sequences of human ${ }^{h}$, pig $^{p}$, and mice ${ }^{m}$ that have homology with the anterior pituitary ESTs. These data were retrieved from NCBI (http://www.ncbi.nlm.nih.gov/BLAST/) using the nr nucleotide sequence database (September, 2002).

${ }^{2}$ Human chromosome location retrieved from NCBI (http://www.ncbi.nlm.nih.gov/) at unigene or locuslink $^{\text {b }}$ (September, 2002).

${ }^{3}$ Alternative RHP assignments were obtained for this gene.

with the SCHP results, an assignment to SSC1 is supported by known pig-human conservation. Markers SF3B1 and Clock were not analysed using the IMpRH.
This report has placed 11 new EST markers on nine pig chromosomes. These data contribute to characterization of the porcine anterior pituitary transcriptome during a defined peri- 
od of follicular development. In the present study, SPARCL1 was assigned within a QTL region for age at puberty previously identified in these selection lines (Cassady et al. 2001). While integration of functional analysis and mapping information identifies SPARCL1 as a positional candidate gene for age at puberty in pigs, the function of this gene is not yet well understood.

\section{Acknowledgements}

We thank S. Olberding and S. Wesolowski for their help with laboratory work. Also we thank CAPES (Brazil) for funding a graduate scholarship for GRB who is an employee of Embrapa (Brazil). This work was partially supported by a subcontract to UNL from USDA-NRI CGP 99-35205-8370 (PI: C.K. Tuggle, Iowa State University). Published as paper number 13766 of the journal series, Nebraska Agricultural Experiment Station.

\section{References}

Bertani G.R. (2001) Gene Expression Analysis in Anterior Pituitary to Investigate Genetics of Swine Fertility, PhD Dissertation. University of Nebraska, Lincoln, NE, USA. 109 p.
Cassady J.P., Johnson R.K., Pomp D., Rohrer G.A., Van Vleck L.D., Spiegel E.K. \& Gilson K.M. (2001) Identification of quantitative trait loci affecting reproduction in pigs. Journal of Animal Science 79, 623-33.

Goureau A., Yerle M., Schmitz A., Riquet J., Milan D., Pinton P., Frelat G. \& Gellin J. (1996) Human and porcine correspondence of chromosome segments using bidirectional chromosome painting. Genomics 36, 252-62.

Hawken R.J., Murtaugh J., Flickinger G.H., Yerle M., Robic A., Milan D., Gellin J., Beattie C.W., Schook L.B. \& Alexander L.J. (1999) A first-generation porcine whole-genome radiation hybrid map. Mammalian $\mathrm{Ge}$ nome 10, 824-30.

Johnson R.K., Nielsen M.K., \& Casey D.S. (1999) Responses in ovulation rate, embryonal survival, and litter traits in swine to 14 generations of selection to increase litter size. Journal of Animal Science 77, 541- 57.

Milan D., Hawken R., Cabau C. et al. (2000) IMpRH server: an RH mapping server available on the Web. Bioinformatics 16, 558-9.

Rozen S. \& Skaletsky H. (2000) Primer 3 on the www for general users and for biologist programmers. Methods in Molecular Biology 132, 365- 86.

Yerle M., Echard G., Robic A., Mairal A., Dubut-Fontana C., Riquet J., Pinton P., Milan D., Lahbib-Mansais Y. \& Gellin J. (1996) A somatic cell hybrid panel for pig regional gene mapping characterized by molecular cytogenetics. Cytogenetics and Cell Genetics 73, 194- 202.

Yerle M., Pinton P., Robic A.et al. (1998) Construction of a whole-genome radiation hybrid panel for high-resolution gene mapping in pigs. Cytogenetics and Cell Genetics 82, 182-8. 